\title{
FOUR WHEELS GOOD?
}

\author{
With the world's love of cars showing little sign of abating, manufacturers are under \\ increasing pressure to make vehicles less polluting and oil dependent. Duncan \\ Graham-Rowe explores some of the technologies that could keep us on the road.
}

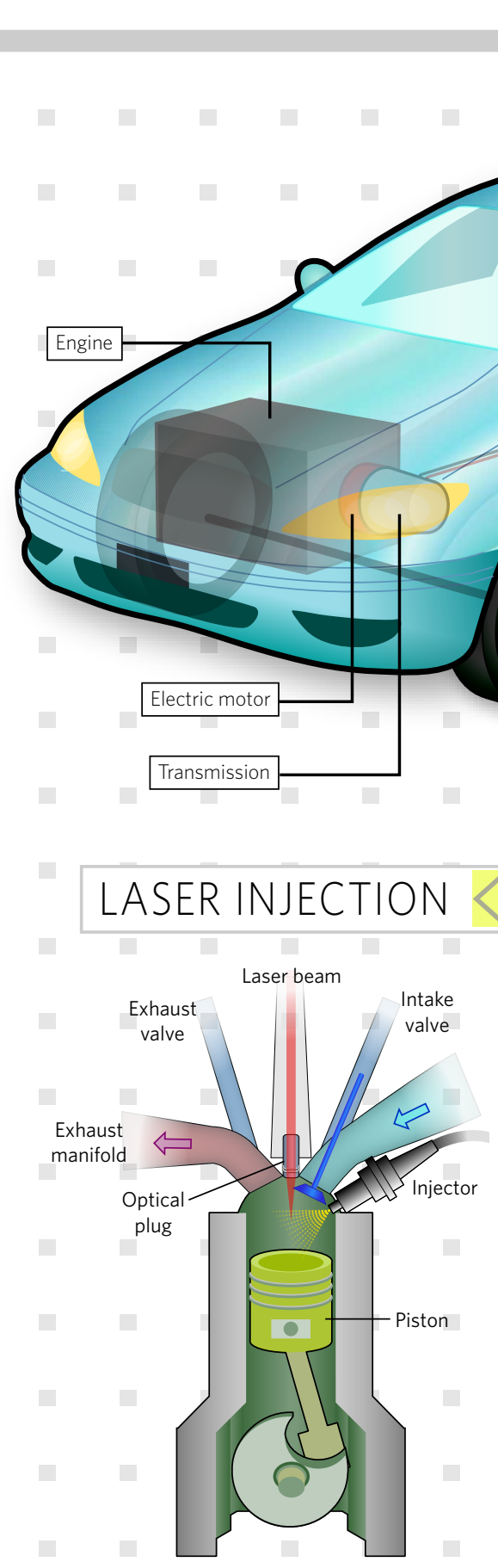

\section{HYBRIDS}

Replacing spark plugs with laser-pulse ignition systems may sound over the top, but it makes sense, says Andrew Scarisbrick, supervisor for UK government and university collaborations at Ford Motor Company's Dunton Research and Engineering Centre near Basildon. Laser ignition systems can reduce fuel consumption and emissions because they give better control of where in the cylinder the spark occurs. Ideally, the spark should be as far from the cylinder walls as possible, so that the flame front is less able to form harmful nitrous oxides. But this technology is still a good few years off, Scarisbrick says. "At the moment the cost is astronomic."
One way to reduce the energy cars consume is to recycle it. Hybrid vehicles use the combustion engine to charge up a battery that provides extra power to the engine when accelerating, thus reducing fuel consumption. 'Regenerative braking', in which the electric motor provides resistance to the drive train to help slow the vehicle, converts the kinetic energy into electricity, which is then stored for later use. The benefits of hybrids can really be seen during town driving - the fuel savings may be only a few per cent on longer trips. Fleets of hybrids could also provide a place to store electricty on a large scale, helping in the use of various renewable technologies (see page 805). 


\begin{tabular}{|c|c|c|}
\hline $\begin{array}{l}\text { One reason electric vehicles have never } \\
\text { taken off is the lack of decent battery } \\
\text { technologies. Lithium-ion batteries are } \\
\text { currently the best candidates for cars } \\
\text { because they deliver power much more } \\
\text { quickly than others. But they only carry } \\
\text { enough charge to last for around } 100 \\
\text { miles before needing recharging. They } \\
\text { also have to be replaced every couple of } \\
\text { years. And in extreme circumstances they } \\
\text { can catch fire or explode. So, many car }\end{array}$ & $\begin{array}{l}\text { manufacturers, including Toyota with the } \\
\text { Prius hybrid vehicle, have opted for nickel } \\
\text { metal hydride batteries, which pack less } \\
\text { punch than the lithium-ion ones but last } \\
\text { longer and are safer. } \\
\text { Companies such as Massachusetts- } \\
\text { based A123Systems are finding new ways } \\
\text { to squeeze more life out of a battery. } \\
\text { The cathodes within batteries degrade } \\
\text { with repeated use and recharging. So } \\
\text { A123Systems has developed a birdcage-like }\end{array}$ & $\begin{array}{l}\text { nanostructure of lithium iron phosphate } \\
\text { surrounding the cathode that prevents it } \\
\text { from expanding and contracting during } \\
\text { charging and discharging, and so stops } \\
\text { the cathode wearing down so quickly. } \\
\text { According to the company, its batteries } \\
\text { have a potential lifetime ten times that of } \\
\text { conventional ones. And although they are } \\
\text { not as powerful as the regular lithium-ion } \\
\text { batteries, they are a vast improvement on } \\
\text { the nickel metal hydride type. }\end{array}$ \\
\hline
\end{tabular}

\section{BETTER BY DESIGN}

\section{CONTROL FREAK}

Even subtle alterations to the way cars handle on roads can improve fuel efficiency. Drive-bywire technology would remove the mechanical linkages between the controls and the brakes, throttle and steering mechanisms. Computers continually interrogate sensors about the car's handling and the road conditions to calculate, for example, the optimal throttle position at that moment. Most countries currently require a mechanical linkage between the steering wheel and wheels themselves, so manufacturers would have to persuade governments that the technology is safe.
The electric two-seater renewable energy vehicle (TREV), developed at the University of South Australia in Adelaide, was designed to carry only two people because, according to its creators, $90 \%$ of urban trips require no more than two seats.

Thinking along similar lines, the Californian company Aptera recently launched a two-seater electric car (pictured) that it claims has the most energy-efficient and lowest-drag shape that can surround two people sitting side-by-side. Even its wing mirrors are replaced with rear-facing cameras and internal monitors. Use of composite materials makes the three-wheeler very light, just 680 kilograms, placing less of a drain on its plug-in electric motor. According to the company, it can go from 0 to 60 miles per hour in ten seconds and has a top speed of $85 \mathrm{mph}$.

\section{HYDROGEN FUEL}

\section{Widely tipped to replace oil as a} transportation fuel, hydrogen has nearly three times the energy density of petrol by mass, and when used to power fuel cells it produces only steam as a waste product. Most large car manufacturers are developing some form of hydrogen-powered car.

But there are major obstacles to overcome before hydrogen could become a mainstream fuel - how to produce, transport and store it. "Hydrogen requires a huge infrastructure change that's not likely to happen for a long time," says David Sims-Williams, an engineer at Durham University, UK. Producing it using renewable sources of energy is extremely inefficient, and the vast majority of hydrogen is currently produced from coal or natural gas, which is less than ideal.
Another major problem is that, even in liquid form, hydrogen has a tenth the density of water. So hydrogen has less than a third of the energy density of petrol by volume. As things stand, a car's fuel tank would not only have to be cooled to below $-250^{\circ} \mathrm{C}$ to keep the hydrogen liquid but would also have to be many times larger than existing ones.

In 2003, the US Department of Energy issued a challenge to scientists to develop new materials that can store enough hydrogen to make up $6 \%$ of the material's total mass. Frantisek Svec at Lawrence Berkeley National Laboratory in California has developed a nanoporous polymer that adsorbs hydrogen atoms reversibly on its surface, allowing much higher densities to be stored. But the hydrogen is only $1.5 \%$ of the polymer's mass, still way short of the target.

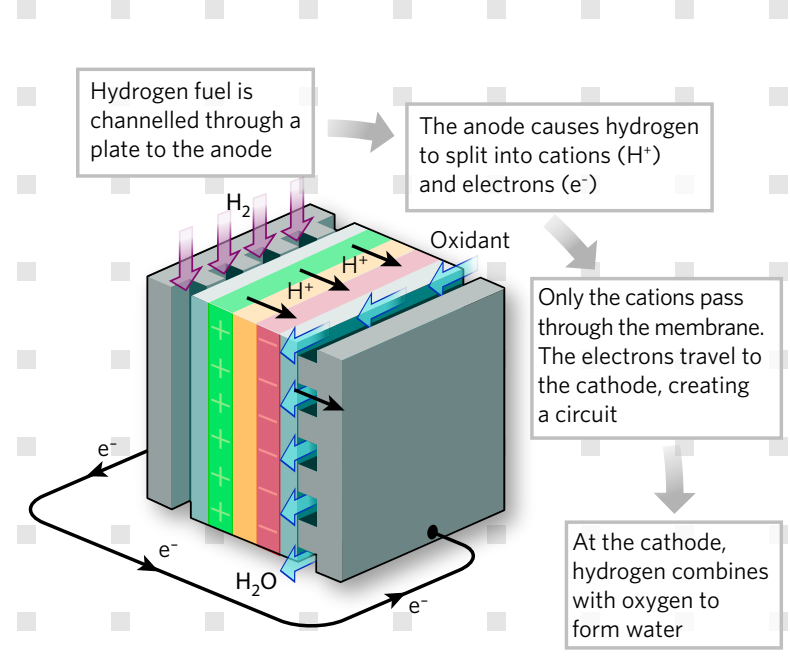

